This is an Open Access article, distributed under the terms of the Creative Commons Attribution licence (http://creativecommons.org/licenses/by/4.0/), which permits unrestricted re-use, distribution, and reproduction in any medium, provided the original work is properly cited.

\title{
A Woman with a Sword? - Weapon Grave at Suontaka Vesitorninmäki, Finland
}

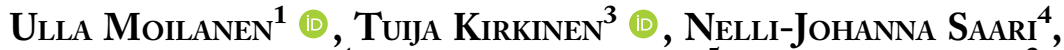 \\ Adam B. Rohrlach ${ }^{4}$ (1) , Johannes Krause ${ }^{5}$ (i), Päıvi Onkamo ${ }^{2}$ and \\ Elina Salmela 6 (ib \\ ${ }^{1}$ Department of Archaeology, University of Turku, Finland \\ ${ }^{2}$ Department of Biology, University of Turku, Finland \\ ${ }^{3}$ Department of Cultures, University of Helsinki, Finland \\ ${ }^{4}$ Max Planck Institute for the Science of Human History, Jena, Germany \\ ${ }^{5}$ Max Planck Institute for Evolutionary Anthropology, Leipzig, Germany \\ ${ }^{6}$ Organismal and Evolutionary Biology Research Programme, University of \\ Helsinki, Finland
}

In 1968, a weapon grave with brooches was found at Suontaka Vesitorninmäki, Hattula, Finland. Since then, the grave has been interpreted as evidence of powerful women, even female warriors and leaders in early medieval Finland. Others have denied the possibility of a woman buried with a sword and tried to explain it as a double burial. We present the first modern analysis of the grave, including an examination of its context, a soil sample analysis for microremains, and an aDNA analysis. Based on these analyses, we suggest a new interpretation: the Suontaka grave possibly belonged to an individual with sex-chromosomal aneuploidy $X X Y$. The overall context of the grave indicates that it was a respected person whose gender identity may well have been non-binary.

Keywords: aDNA, burial archaeology, Klinefelter syndrome, XXY, sword graves, gender archaeology

\section{INTRODUCTION}

There is an enduring fascination with women buried with weapons, but the topic continues to be debated (e.g. Androshchuk, 2018; Price et al., 2019). A specific Finnish find, an early medieval inhumation grave dated to $(\mathrm{AD} \quad 1050-1300)^{1}$ found at

1 In Finnish archaeology, the Viking Age (AD 8001025/1050) and Crusade period (AD 1025/1050-1300) are usually considered to belong to the Late Iron Age. Here we refer to both of these periods as early medieval.
Suontaka Vesitorninmäki in the municipality of Hattula (formerly Tyrväntö) (Figure 1), has often been interpreted as a woman buried with two swords. The interpretation is based on dress accessories and jewellery, which suggest that the individual was dressed in feminine clothes. For decades, the grave has been a popular example of powerful women in Late Iron Age and early medieval societies (LehtosaloHilander, 1983: 304, 402-03; Ojanen, 2002: 47; Huurre, 2009: 213). At the 


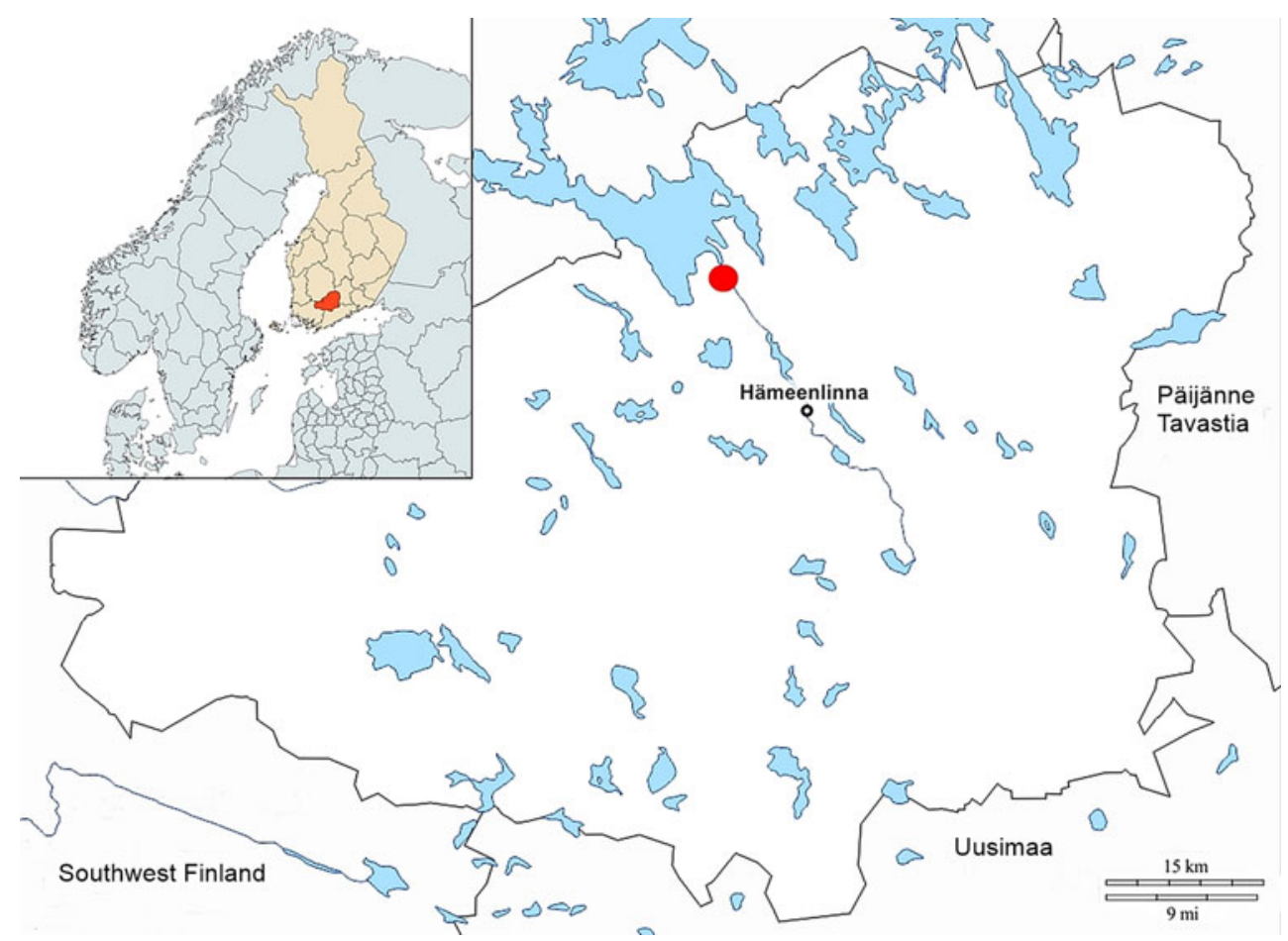

Figure 1. Location of the Häme (Tavastia) region in Finland, with Suontaka marked with a red dot.

National Museum of Finland's permanent exhibition between 1995 and 2016, the grave was used as evidence of female leaders in the past (Erä-Esko et al., 1995: 45). In popular discussions and contexts, for example history forums on the internet, international sword replica shops, and even in the controversial 'Meet the Viking' exhibition at the National Museum of Denmark (see Pentz et al., 2019; Sindbæk, 2019), the decorated bronze-hilted sword allegedly found in the Suontaka burial is presented as a female warrior's weapon.

In this article, we present the first detailed study of the Suontaka grave. We undertook a careful analysis of the original field documentation to determine whether the grave had initially been a double burial, and to provide clarification on its context. To investigate the grave's original context in detail, we conducted a study of microscopic animal hair and fibre remains from the soil retrieved from the grave. Lastly, we studied ancient DNA (aDNA) from the skeletal remains to infer the chromosomal sex of the individual. We conclude the article by drawing the results of these analyses together and discuss their possible meaning in the framework of gender archaeology.

\section{Sex And Gender: A Complex Issue}

The archaeological literature is full of men and women. For decades, buried individuals have been interpreted as male or female based on grave goods, and the development of osteology and genetics have brought in new methods to determine human remains as either female or male. This binary division is, however, problematic. Chromosomal aneuploidiesas well as certain genetic and hormonal conditions-widen the variation in 
biological sex (Sofaer, 2006: 157; FaustoSterling, 2020: 74-76), but biology itself offers little in terms of a person's self-identification. Some recent studies suggest that brains produce personality, cognition, and behaviour similarly regardless of chromosomal sex, in opposition to the idea that binary female and male differences exist in the brain (Joel et al., 2015, 2020).

In the 1970s, it became common to distinguish biological sex from socially and culturally defined gender (e.g. FaustoSterling, 2020: 14-16 with references). This concept has since been developed further. Butler (1990) has argued that sex and gender are interlinked social constructs: gender is a performance based on the expectations of society, a set of norms associated with a certain kind of body. While social gender can be understood as representing culturally specific expectations of behaviour, sex can be understood as a common agreement on certain chromosomal, hormonal, anatomical, and physical features (Butler, 1990; Fausto-Sterling, 2012, 2020).

The binary division of sexes is arguably rooted in a modern, western mindset, and gendered norms and expectations have varied culturally, geographically, and temporally (e.g. Laqueur, 1990: 6-12; Comaroff \& Comaroff, 1992: 78; Motschenbacher, 2010: 13). Early medieval societies evidently had their own expectations and norms for female- and male-bodied individuals, but were these norms inflexible and exclusive? And how were they negotiated and displayed in different circumstances? The traditional view emphasizes rigid masculine ideals (e.g. Clover, 1993; Hedeager, 2011), but many recent studies indicate that early medieval societies understood and performed gender in diverse and nuanced ways (e.g. Back Danielsson, 2014; Moen, 2019). This encourages us to think about a gender spectrum instead of a binary gender division (Moen, 2019: 217).
The complexity of gender is evident in the problem of determining the sex or gender of individuals based on the artefacts recovered from their graves (e.g. Berg \& Lie, 1995; Effros, 2000; Stratton, 2016). It is unclear how well the grave goods represent the gender roles and identities of the past, and whether these roles should be interpreted from a binary perspective (e.g. Hjørungdal, 1994; Nixon, 1994; Conkey \& Gero, 1997; Gilchrist, 1999; Sørensen, 2000; Joyce, 2008; Hedenstierna-Jonson et al., 2017; Moen, 2019; Price et al., 2019). Although swords in early medieval graves in northern Europe can be interpreted in many ways, from symbols of power and social status to ancestral heirlooms (Hadley, 2008: 273; Gardela, 2013; Härke, 2014; Harrison, 2015), they are still often associated with masculinity and warrior ideology (see e.g. Jakobsson, 1992; Petré, 1993; Raninen, 2006: 4; Hadley, 2008; Hedeager, 2011: 118, 124; Harrison, 2015; Sayer et al., 2019: 561). While axes, spearheads, and arrowheads have occasionally been buried with female-bodied people, and may appear in graves together with feminine jewellery (e.g. Mägi, 2002: 77-79; Gardela, 2013; Moisio, 2016; Lund \& Moen, 2019), swords are rare items in graves of female-bodied individuals (Raninen, 2005: 229; Wessman, 2010: 102; McLeod, 2011: 343; Raninen \& Wessman, 2016: 319-20). An interesting aspect of the graves containing osteologically determined females and swords is that they often lack jewellery and other feminine accessories (Simniškyte, 2007; Price et al., 2019). This is seemingly in line with the idea that the Scandinavian gender system accepted masculinity as the only normative gender and allowed only some females to obtain masculine gender in certain circumstances (Clover, 1993). Weapons are often considered non-normative items in women's graves, and the 
emphasized masculine symbolism of swords is the reason why graves containing both 'typically' feminine and masculine items are often considered problematic. The combined presence of weapons and jewellery in graves easily leads to interpretations of mixed gender double burials, even if the context indicates only a single skeleton in the grave (see Nylén, 1973: 165; Taavitsainen, 1990: 91; McLeod, 2011: 343; Androshchuk, 2018). However, as Moen (2019) has pointed out, the graves may not tell us about the gender systems of the past per se, but rather about the assumptions of the modern people making the interpretations.

\section{The Context of the Suontaka Grave}

The Suontaka grave is famous for its bronze-hilted sword (National Museum of Finland, hereafter NM, accession number 17777:1), decorated with Urnes style ornaments (Keskitalo, 1969b) (Figure 2A). The other finds include a less-discussed, hiltless sword blade (NM 17777:2) with silver inlays, a sheathed knife (NM 17777:3), two oval brooches (NM 17777:4-5), a twin-spiral chain-bearer (NM 17777:6), a small penannular brooch (NM 17777:7), and a sickle (NM 17777:8) (Figure 2B-G). Of these items, the swords are traditionally associated with males and jewellery with females. In Finland, sickles are common in both feminine and masculine graves, although they are slightly more frequently associated with females than with males (LehtosaloHilander, 1982: 54-55). The typological dating of the artefacts indicates that the burial took place in the late eleventh or early twelfth century $\mathrm{AD}$ (Taavitsainen, 1990: 91), which coincides with the Crusade period (AD 1025-1150) in the western Finnish chronology. Radiocarbon dating supports this, as a femur fragment from the grave gave a date of $921 \pm 17 \mathrm{BP}$ (Hela-4566), i.e. AD 1040-1174 at 95.4 per cent; (date modelled in OxCal v4.4.2 (Bronk Ramsey, 2017), using the IntCal13 atmospheric curve (Reimer et al., 2020)).

The original excavation report from 1969 describes the Suontaka grave and the finds in detail (Keskitalo, 1969a). The excavation was carried out in late October 1968 after the bronze-hilted sword was found by water pipeline workers. Oiva Keskitalo, who excavated the site, noticed a dark-coloured area-the grave cut-in the water pipe trench. According to his description, the dark area was the grave pit's upper right corner, where the bronzehilted sword had been located (Keskitalo, 1969a). Although Keskitalo does not mention the exact distance between the sword and the other finds, his photographs indicate that he had to remove some of the dark soil before reaching the skeletal remains and the other artefacts. This suggests that the bronze-hilted sword may have been located in the grave fill, and therefore it is unlikely to be directly associated with the burial assemblage. No other graves are known from the vicinity, and it is unknown whether the burial represents a solitary burial or whether it is part of a larger cemetery.

In the literature, the Suontaka burial has been called 'partly destroyed' because of the bronze-hilted sword find and the manner of its discovery. Jussi-Pekka Taavitsainen, who has been critical of its interpretation as a female weapon burial, emphasizes the unreliability of the find context by saying that the grave was excavated in 'difficult conditions' (Taavitsainen, 1990: 91). Although the excavation was carried out in late autumn when the temperature had dropped to $-10^{\circ} \mathrm{C}$, Keskitalo states in his original report (1969a) that only the surface of the ground was frozen. This suggests that the conditions at the bottom of the 


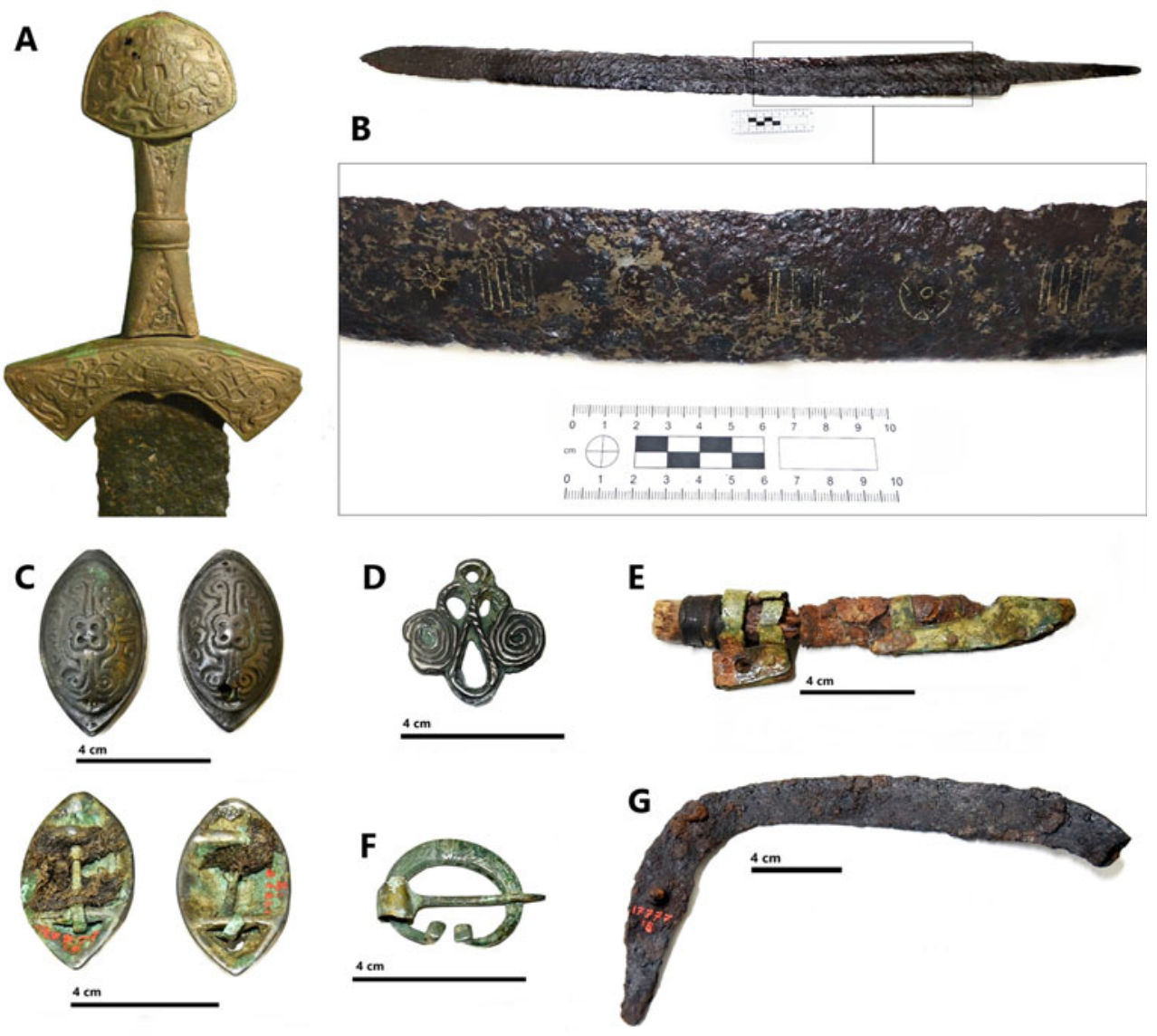

Figure 2. The objects found in the Suontaka grave. A: bronze-hilted sword (NM 17777:1); B: biltless sword (NM 17777:2) with silver inlays (inset); $C$ : two oval brooches with textile fragments (NM 17777:4-5); D: twin-spiral chain-bearer (NM 17777:6); E: sheathed knife (NM 17777:3); F: penannular brooch (NM 17777:7); G: sickle (NM 17777:8). A: @ Finnish Heritage Agency.

grave pit $(70-90 \mathrm{~cm}$ from the topsoil) where the skeleton was lying, were not significantly different from those of summertime excavations. ${ }^{2}$ Therefore, the field observations should be considered reliable. The position and the shape of the skeleton were observed and documented: the tibias, femora, pelvis, elbow joints, ribs, and skull

2 Finland is located in an area where the ground is seasonally frozen. The maximum soil frost depth depends on various factors, but rarely extends over 100$150 \mathrm{~cm}$ in areas covered with snow (Venäläinen et al., 2001). Thus, burials at a depth of $c .100 \mathrm{~cm}$ are not considerably affected by seasonal frost. were in situ (Figure 3A). Although observable, the bones were almost fully decomposed and consisted of a soft mass, and only fragments of two femora (NM 17777:9) could be lifted from the ground.

As mentioned, it is rare in a Nordic context to find a sword in a grave with several artefacts with feminine gender association. Because of the unusual combination of objects, it has been suggested that there must have been two individuals in the grave (Nylén, 1973: 165; Taavitsainen, 1990: 91). Keskitalo was himself puzzled by the fact that the 
A

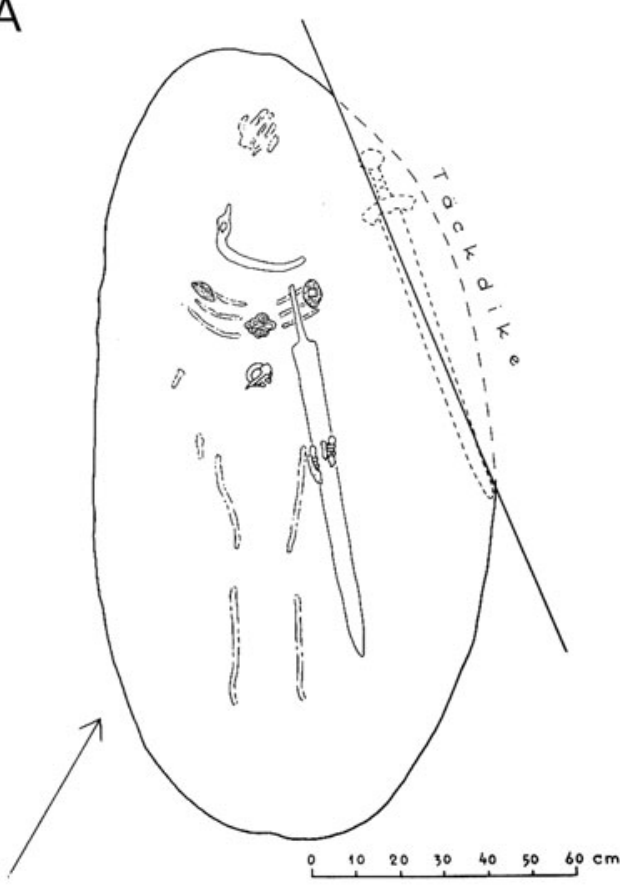

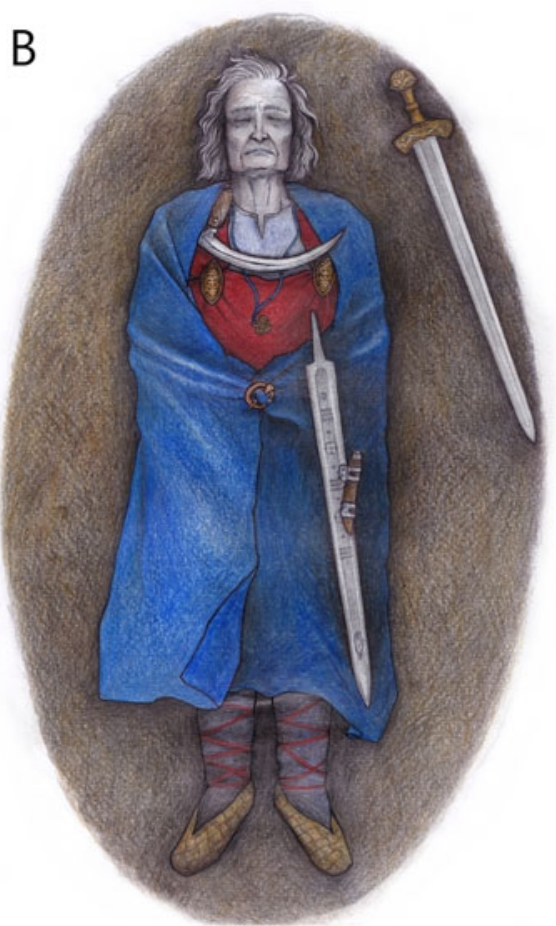

Figure 3. A: plan of the Suontaka burial. 'Täckdike' marks the water pipe trench which led to the discovery of the grave (Keskitalo, 1969b: 85). B: artist's reconstruction of the burial, showing the position of the objects on the body. A reproduced by permission of Finnish Heritage Agency. B: drawing by Veronika Paschenko.

skeleton was equipped with two brooches (usually considered part of feminine dress, see Lehtosalo-Hilander, 1984) and a sword (traditionally associated with male burials), and he tried to find evidence of more than one individual in the grave without success. Keskitalo (1969a, 1969b) observed that the burial pit had an even floor, where the corpse had been placed in a supine position without a coffin. The size of the pit was suitable for only one corpse. If there had been another, it would have been on top of the first. Although placing several bodies in the same grave on top of each other may influence the decomposition process by accelerating the speed of decay in the uppermost bodies (Troutman et al., 2014), it is implausible that the Suontaka grave was initially made for two people. No different colouring of the soil indicated another decomposition layer, and no other artefacts were observed in the upper parts of the grave. Even if there had been another corpse above the documented skeleton, its only accompanying item would possibly have been the bronze-hilted sword.

Apart from the bronze-hilted sword, all the other objects were directly connected with the skeletal remains (Figure 3A). The hiltless sword blade was located on the left side of the pelvis and the sheathed knife on top of the sword's blade. Two oval brooches with woollen textile fragments were located below the shoulders, indicating that the individual had been buried in a typical feminine costume of the era (see Lehtosalo-Hilander, 1984). The twin- 
spiral chain-bearer was located on the chest, between the brooches. Based on its position, and on the fact that no chain loops were found from the grave, the object may have been used as a pendant and not as a chain-bearer, the latter being a distinctive artefact in typical female graves (Figure 3B). The penannular brooch was found approximately at the waist level, and the sickle had been placed on the individual's upper chest. Items placed on the chest or stomach might move slightly downwards during the decomposition of soft tissues, but as the burial did not contain a coffin, the sandy soil constantly replaced the decaying tissues (Duday, 2009). The displacement of objects and bones is therefore not as extensive as when decomposing in a void created by a coffin or other structure. Because of this, it seems clear that all the items-except the bronzehilted sword-were placed directly on the body. Hence, these artefacts can be associated with the buried individual, and not another corpse that would have completely decomposed.

\section{Fibres and Animal Hairs in the Grave}

Separate soil samples were not taken from the grave during the excavation, but the femur fragments were lifted from the ground with a small amount of soil. This soil represents the original material in the grave, in direct contact with the buried body. The soil was analysed for possible animal hairs and textile fibres (see Supplementary Material 1 for details and methods).

In total, twenty-three mammalian hairs and three bird feather fragments were extracted from the sample (Supplementary Material 1, Table S1). Most of the hairs were very short, from 0.2 to $2 \mathrm{~mm}$ long, and for this reason, only part of them could be identified to species or family level. Some 60 per cent of the hairs $(n=$ 14), were identified as belonging to sheep (Ovis aries) fine hairs, i.e. wool (Figure 4C). Most were natural white ( $\mathrm{n}=$ $6)$ or brown $(n=3)$, and single hairs were coloured blue $(n=2)$ or blueish/green $(n=$ 3). Seven non-medullated, colourless hairs were not identifiable. It is possible that at least some of these might have been fine hairs from sheep, too. In addition to wool fibres, a fine hair of a fur-bearing animal, probably red fox (Vulpes vulpes) or a Mustelid, and a fine hair of a rabbit or hare (Leporidae) were discovered (Figure 4A-B). The latter was exceptional because it was purple in colour, although that might be of secondary origin. Besides mammalian hairs, three minuscule (0.2$0.5 \mu \mathrm{m})$ bird feather fragments, so-called barbules, were discovered (Figure 4D). These fragments showed no diagnostic features for species identification.

\section{Determining the Chromosomal SeX}

As bone material from the Suontaka grave consists of only two highly degraded femur fragments, an osteological analysis could not be carried out. Ancient DNA (aDNA) analyses, on the other hand, may be used to infer the chromosomal sex of an individual even from low quantities of skeletal material (Reich et al., 2010). We extracted and sequenced aDNA from one of the femur fragments in the archaeogenetics laboratory of the Max Planck Institute for the Science of Human History in Jena, Germany (see Supplementary Material 2 for a detailed description of the laboratory analysis protocols). Unfortunately, the sample gave a very low yield of endogenous human DNA: even after a capture procedure to enrich for human DNA, the data contained only 106,781 sequence reads mapping to the human genome (of a total 


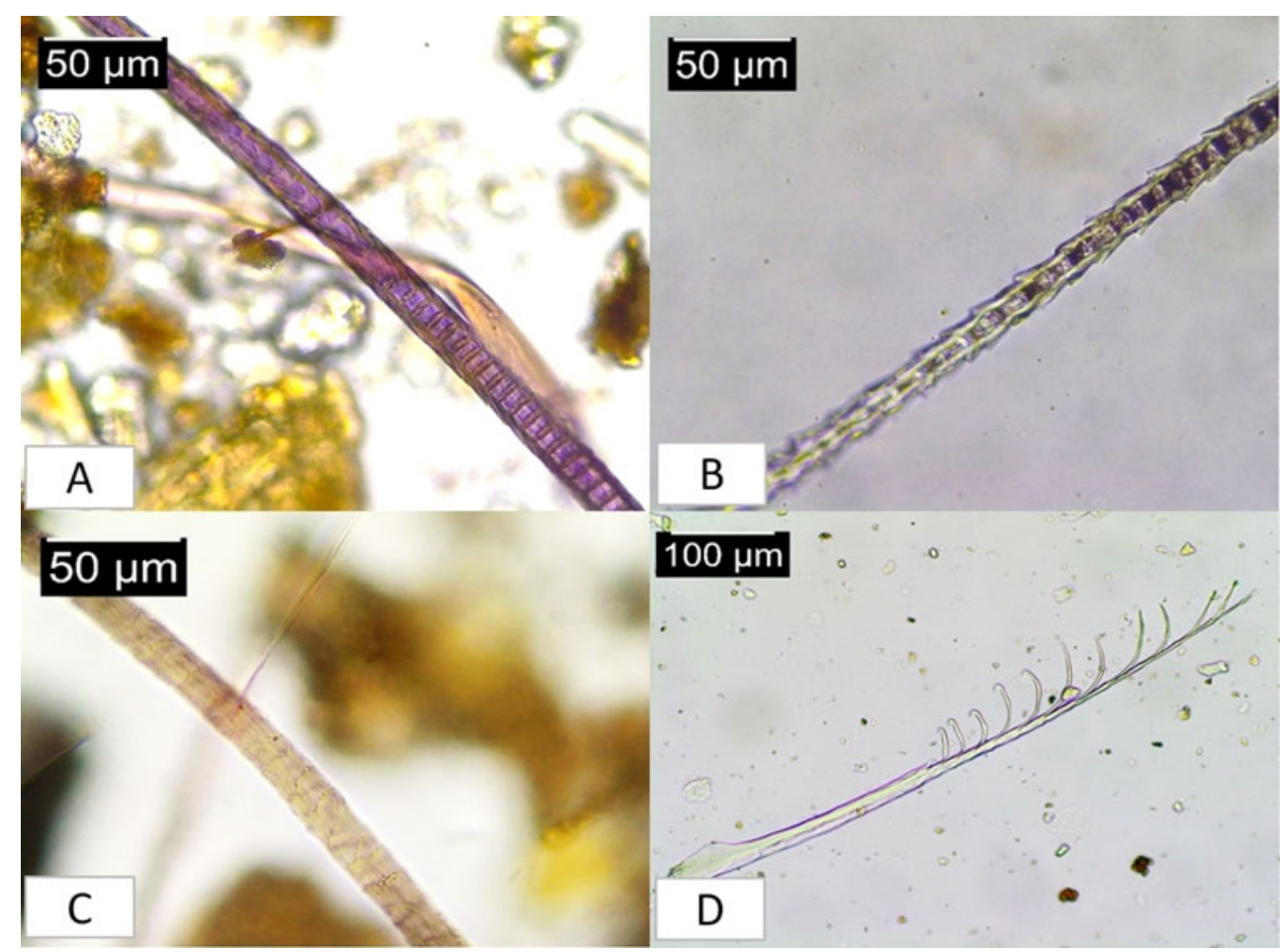

Figure 4. Examples of identified animal hairs from the soil sample. A: Leporidae (see Supplementary Material 1, Table S1, K3); B: Vulpes vulpes or Mustelidae (K20); C: Ovis aries (K13); D: Aves (K19).

of $18,250,176$ overall reads), 8329 of which had a mapping quality above 30 . Of these, 2534 also showed post-mortem damage (PMD) scores above 0 from PMDtools (Skoglund et al., 2014) (Supplementary Material 2, Table S2). This paucity of data seriously limited the range of aDNA analyses that could be conducted, including those for data authentication (see Supplementary Material 2). Therefore, we did not extend our genetic analyses beyond sex determination, as that is among the analysis types that need the least amount of data.

Existing methods for chromosomal sex determination (Skoglund et al., 2013; Fu et al., 2016; Mittnik et al., 2016) lack power for data as sparse as this, but their results suggested that the Suontaka individual's X-chromosomal and Y- chromosomal read counts fit neither those expected for XX (female) nor for XY (male) individuals. We therefore developed a novel approach to estimate the chromosomal sex of the individual, where we downsampled sequencing reads from individuals of known genetic sex to the number of reads observed in the Suontaka individual $(\mathrm{n}=8329)$ to model four possible scenarios that could have produced the observed data: XX, XY, a contaminated sample with a mix of reads from $X X$ and $X Y$ individuals, and an aneuploidic karyotype XXY (male with Klinefelter syndrome). The details and assumptions of the model are described in the Supplementary Material 2.

Despite the extremely low sequencing coverage, we found overwhelming evidence that the genetic data of the 
Suontaka individual most closely resemble an XXY karyotype: our model classified the Suontaka individual as XXY at a 99.75 per cent probability, as contaminated with a 0.25 per cent probability, and as $\mathrm{XX}$ or $\mathrm{XY}$ with a very low probability (less than $10^{-6}$ in either case). In a subset of data that was enriched for plausibly ancientlooking reads $(n=2534)$, the corresponding probabilities were 99.96 per cent for XXY, 0.04 per cent for contamination, and again negligible for $\mathrm{XX}$ and $\mathrm{XY}$; it therefore seems that the XXY signal in the data is not driven by potential modern contaminating DNA. Even when we take into account the low population frequency of the XXY karyotype, the XX and XY scenarios remain extremely unlikely, andunless we assume a considerably high prior probability of contamination - the Suontaka individual's karyotype is still most likely to be XXY.

The condition in which males are born with one or more extra $\mathrm{X}$ chromosomes is known as Klinefelter syndrome. With its prevalence of 1 in 576 male births, $\mathrm{XXY}$ is the most common sex-chromosomal aneuploidy in humans (Nielsen \& Wohlert, 1991). The clinical signs of karyotype XXY vary from very subtle and unnoticeable to apparent differences in physical features. The anatomical appearance of $\mathrm{XXY}$ individuals is male, and some of them never even notice that they have the condition. In some cases, the clinical signs are stronger: XXY males can be infertile and have hypospadias (the opening of the urethra is on the underside of the penis), small phallus and testicles, and gynecomastia (breast growth). Testosterone deficiency may cause delayed or incomplete pubertal development. Sometimes effects on physical and cognitive development are reported and, according to some studies, modern XXY males may consider themselves more sensitive and unassertive than others (Visootsak \& Graham, 2006).
Interviews also suggest gender-related insecurities stemming from the XXY males feeling physically more feminine than other males (Berch \& McCauley, 1990). Because the modern XXY males may compare their experiences to modern expectations of sex and gender, it is difficult to say how the physical and possibly psychological aspects would have been understood and displayed in eleventhtwelfth-century Finland.

\section{Discussion}

The context of the Suontaka grave indicates that the burial belongs to only one individual, dressed in clothes typically gendered feminine. Although the grave includes a hiltless sword placed directly on the corpse, the other, bronze-hilted, sword is unlikely to come from the burial assemblage as it was found in the upper layers of the grave. It is possible that the sword was deliberately hidden or placed in the grave afterwards, perhaps by the next generation. According to literary sources, hiding swords in secure places, such as burial mounds, for magical purposes was common in the past (Wessman, 2010: 97 with references). The placement of the hiltless sword is, on the other hand, significant, as swords placed directly on the body may be interpreted as strong symbols of identity and personhood (Sayer et al., 2019). The hiltless sword does not bear evidence of battle damage, and the handle has been removed as if to make it unusable, or less violent and genderless if the traditional perspective on the symbolism of swords is followed. Alternatively, the hilt may have been made of organic materials. The fact that the sword may have been unusable is of interest, since the area of Häme seems to have been a turbulent and violent area at the time the burial took place. This is indicated by a large 
number of hillforts in the area (Taavitsainen, 1990: 133-46; Ojanen, 2002: 47) and by battle damage features on several other contemporary swords in the region (Moilanen, 2015: 99-100, 104).

The fibres discovered in the soil around the femora provide evidence for the presence of woollen textiles, furs, and bird feathers in the grave. The new analysis indicates that the textiles were made of natural white and brown as well as blue or blueish yarns. Red fox or Mustelidae species hair imply a garment made of fur or animal skin, although one hair is insufficient to reach further conclusions. In other Finnish early medieval burials, fur and animal skins have been used for linings, mitten, pouches, and knife sheaths in about sixteen per cent of the studied burials (Kirkinen, 2015, 2019: 54-55, 6567). The Suontaka grave also contained a hair of a rabbit or hare (Leporidae). In Rast-Eicher (2016: 150-52), there are references to the blending of rabbit hairs with wool, and to luxurious rabbit fibre textiles. The Suontaka bird feather fragments are likely to be the remains of a pillow or bedding. Similar material has occasionally been found in Scandinavian Viking Age burials (Dove \& Wickler, 2016; Rast-Eicher, 2016: 291) and in single cases in Finland (Kirkinen, 2015: 107; Kirkinen et al., 2020). Overall, the furnishing of the grave suggests an elaborate burial that possibly contained feather bedding and fur garments made of prestigious animal pelts, which were often traded further and not used by the hunters or traders themselves (Kirkinen, 2019).

The aDNA-based sex determination was complicated by the very small amount of endogenous DNA in the sample. Notably, most uncertainty in the Suontaka individual's karyotypic result concerns the presence of a Y chromosome. Whereas the observed number of $\mathrm{X}$-chromosomal reads is clearly in line with the presence of two $\mathrm{X}$ chromosomes rather than one, the smaller size of the $\mathrm{Y}$ chromosome leads to a lower number of expected reads, more prone to sampling errors. The observed number of Y-chromosomal reads is at the low end of the distribution expected in the presence of one $\mathrm{Y}$ chromosome-but still higher than that expected for XX individuals. Through modelling, we were able to show that even when taking into account the possibility of human DNA contamination, it seems likely that the individual had male chromosomal aneuploidy XXY (Klinefelter syndrome). This is not unprecedented, as archaeological cases of Klinefelter syndrome (XXY) have been reported earlier: there is a case from Viking Age Iceland (Ebenesersdóttir et al., 2018), one in early Neolithic Germany (Rivollat et al., 2020), and possibly one from the Orkney Islands in the Viking Age (Margaryan et al., 2020), but the find contexts of these individuals have not been reported as atypical. Therefore, to our knowledge, Suontaka would be the first case of chromosomal aneuploidy from a context which has been puzzling archaeologists as an atypical combination of mixed-gender attributes.

While Klinefelter syndrome would be an intriguing explanation behind the mixed-gender grave goods of the Suontaka burial, it is important to remember that chromosomal sex is different from gender, and karyotype XXY does not automatically define an individual's gender identity or even anatomical appearance (see Herlihy \& Gillam, 2011). Biological sex variations have several contributing factors, and all chromosomal sexes may identify themselves as male, female, or anything outside the binary. Regardless of karyotype or anatomical appearance, the Suontaka individual too could have identified themself anywhere in the gender spectrum (see Moen, 2019). 
We can, however, consider the implications if the Suontaka individual had noticeable symptoms of Klinefelter syndrome. The individual's age at death is unknown, but it could be speculated that if they lived through puberty, this could have been the time when the physical signs became more obvious due to the lack of testosterone. If the early medieval society divided individuals into men and women based on certain characteristics, the pubertal changes-or the lack of them - could have led the individual being associated with a non-binary gender role. Although chromosomes do not define gender identities, sex, gender, and sexuality are important aspects of how identity and personhood are constructed. In a wider context, they are also vital in how the society perceives the individual. Gender roles are not necessarily personal choices but shaped by society (see Butler, 1990; Fausto-Sterling, 1992, 2020). In early modern Finland, the masculine roles were sometimes dependent on sexual ability and capability of producing offspring (Stark-Arola, 1998: 34). An infertile man, which an XXY male is likely to have been, could have lost his manliness in the eyes of society.

Clothes and adornments are important expressions of persons, and integral in how gender is presented and communicated (Sørensen, 2000; Hedeager, 2011: 125; Fausto-Sterling, 2012: 23). The significance of appearance is evident in medieval literature, in which female warriors are described as cross-dressers adopting male outfits (Hedeager, 2011: 121). In early modern rural Finland, clothes were strongly associated with anatomical sex, and cross-dressing individuals were thought to be anatomically ambiguous and often called hermaphrodites (Löfström, 1998: 244-46). From this perspective, the gender-mixing features in the Suontaka burial could easily be explained by bodily differences or a belief that they existed. However, the examples we listed from medieval and early modern contexts would indicate a negative attitude towards the individual, which is in contrast with the elaborate Suontaka burial: the individual was dressed in warm, woollen clothes and furs, equipped with jewellery, a sickle, and a sword, and placed on feather bedding as if to ensure gentle rest.

It has been suggested that, in the ultramasculine environment of early medieval Scandinavia, men with feminine social roles and men dressing in feminine clothes were disrespected and considered shameful (e.g. Price, 2002; Raninen, 2008: 24; Hedeager, 2011: 127-28). At the same time, some evidence suggests that crossdressers and gender-bending ritual specialists could have maintained their own social niche and been tolerated in society (e.g. Zachrisson, 1997: 148; Solli, 1999a, 1999b; Price, 2002: 271-72; Raninen, 2008; Weismantel, 2013: 320), a contradiction possibly deriving from an idea that Odin himself was associated with feminine magic (Solli, 1999a). While the magic practised by male shamans and sorcerers may have been considered unmanly and feminine in Scandinavia (Wallis, 2001: 223; Hedeager, 2011: 128), we could consider the possibility of such practitioners being respected and valued members in the neighbouring Finnic and Sámi communities. In this sense, the Suontaka burial resembles a twelfth-century grave excavated in Vivallen, Sweden, in which a biological male was buried in a feminine dress and accompanied with typically masculine items. The Vivallen individual has been interpreted as a gender-mixing shaman, possibly belonging to Sámi culture (Zachrisson, 1997: 148-49; Price, 2002: 271-73).

The idea of binary gender assumes that there is a strict way of being a man or a woman, but graves like Vivallen and 
Suontaka suggest that this may not have always been the case. The Suontaka burial could be seen as evidence of non-binary gender identities being given a prominent value and visibility in early medieval northern European society. The individual could have been a respected member of a community because of their physical and psychological differences from the other members of that community; but it is also possible that the individual was accepted as a non-binary person because they already had a distinctive or secured position in the community for other reasons; for example, by belonging to a relatively wealthy and well-connected family. This kind of household would have been able to acquire swords, which were presumably among the most valuable and exclusive artefacts available in the region (Moilanen, 2015: 310). The Suontaka individual seems to be local rather than a stranger, as the brooches in the grave belong to the so-called 'Hauho' type, typical to the area (Taavitsainen, 1990: 91); a least, nothing in the jewellery and equipment indicates other than a local origin for the individual. In this respect, the individual is unlike the rare Scandinavian graves of biological males buried with feminine dress and jewellery who are sometimes interpreted as possible strangers, newcomers, and trespassers, and whose funerary rites represent deliberate humiliation (Hedeager, 2011: 126-27).

Early medieval Suontaka was located in a central area, with numerous archaeological sites, such as a hillfort, sacrificial stones, cemeteries, and settlement sites surrounded by ancient fields (Keskitalo, 1969b; Ojanen, 2002: 47). Oral tradition also refers to an ancient assembly site, and Ojanen (2002: 47) considers Suontaka to be the most important village in the region. The wealth and importance of Suontaka have been explained by the fur trade (Keskitalo, 1969b: 96). The elaborate furnishing in the Suontaka burial, i.e. the feather bedding, the fine fur clothes, and the silver-inlaid sword, indeed indicate wealth and long-distance connections. If the Suontaka individual was a member of a powerful and influential local family, as Ojanen (2002: 47) has suggested, that status might have allowed more freedom and possibilities in expressing individual gender identities. A secure social position may have also enabled untraditional life choices that would otherwise not have been tolerated. It may also be possible that the strict binary models proposed for Late Iron Age and early medieval gender are not always holding true (see Moen, 2019). Burial ritual can be considered an intentional display of interpersonal relations and identities. In the Suontaka burial, the people who performed the burial ritual gave the dress, the jewellery, and the weapon prominence. It is therefore possible that the Suontaka individual was not simply a cross-dressing shaman or a person who was forced into a female outfit, but an individual who was accepted and allowed to express their gender identity freely, and had or attained a relatively high status in their society. The later addition of a spectacular sword in the grave possibly highlights the importance of the individual in the memory of the succeeding generation.

\section{Conclusion}

The Suontaka burial has previously been interpreted as a woman buried with two swords. The grave is exceptionally equipped, with several signs of wealth and care, including prestigious furs and rare feather bedding. However, only one sword, hiltless and silver-inlaid, can be conclusively associated with the burial assemblage. The 
bronze-hilted sword was possibly placed in the grave some time after the burial. Our aDNA analysis suggests that the individual may have had an aneuploid male karyotype XXY (Klinefelter syndrome). These new research results indicate that even in early medieval Finland, which is often considered a masculine and warlike society, there may have been individuals who did not fit into a binary gender model. These individuals could also have been respected and considered important, and their gendered identities could be elaborately represented and remembered in the content of their burials.

\section{Supplementary Material}

To view supplementary material for this article, please visit https://doi.org/10.1017/ eaa. 2021.30

\section{ACKNOWLEDGEMENTS}

This work was supported by grants from the Jalmari Finne Foundation, Kone Foundation, Jane and Aatos Erkko Foundation, Jenny and Antti Wihuri Foundation, Ella and Georg Ehrnrooth Foundation, and the European Research Council (ERC) under the European Union's Horizon 2020 research and innovation programme under grant agreement no. 771234 - PALEoRIDER. We wish to thank Prof. Jussi-Pekka Taavitsainen, Dr Stephan Schiffels, Dr Anna Wessman, Heli Etu-Sihvola, Sofia Paasikivi, and Sami Raninen for their valuable comments and discussions on the subject and the themes of this article in manuscript. We also thank Dr Krista Vajanto for the comments on Leporidae hair colour, Marieke van de Loosdrecht for helping with the additional lab work, and the four anonymous reviewers for their comments.

\section{REFERENCES}

Androshchuk, F. 2018. Female Viking Revisited. Viking and Medieval Scandinavia, 14: 47-60. https://doi.org/10. 1484/J.VMS.5.116389

Back Danielsson, I.-M. 2014. Handlingar på gränsen. En hypotes kring hetero- och homoerotiska uttryck på heliga Helgö och närliggande Hundhamra under yngre järnålder. In: H. Alexandersson, A. Andreeff \& A. Bünz, eds. Med hjärta och bjärna: En vänbok till professor Elisabeth Arwill-Nordbladh. Göteborg: Göteborgs universitet, pp. 259-75.

Berch, D.B. \& McCauley, E. 1990. Psychosocial Functioning of Individuals with Sex Chromosome Abnormalities. In: C.S. Holmes, ed. Psychoneuro-Endocrinology: Brain, Behavior, and Hormonal Interactions. New York: Springer, pp. 164-84.

Berg, A.-M. \& Lie, M. 1995. Feminism and Constructivism: Do Artifacts Have Gender? Science, Technology, \& Human Values, 20: 332-51.

Bronk Ramsey, C. 2017. Methods for Summarizing Radiocarbon Datasets. Radiocarbon, 59: 1809-33. https://doi.org/ 10.1017/RDC.2017.108

Butler, J. 1990. Gender Trouble: Feminism and the Subversion of Identity. New York \& London: Routledge.

Clover, C.J. 1993. Regardless of Sex: Men, Women, and Power in Early Northern Europe. Speculum, 68: 363-87.

Comaroff, J. \& Comaroff, J. 1992. Ethnography and the Historical Imagination. San Francisco (CA) \& Oxford: Westview Press.

Conkey, M.W. \& Gero, J.M. 1997. Programme to Practice: Gender and Feminism in Archaeology. Annual Review of Anthropology, 26: 411-37.

Dove, C. \& Wickler, S. 2016. Identification of Bird Species Used to Make a Viking Age Feather Pillow. Arctic, 69: 29-36. https:// doi.org/10.14430/arctic4546

Duday, H. 2009. The Archaeology of the Dead: Lectures in Archaeothanatology. Oxford: Oxbow Books.

Ebeneserdóttir, S.S., Sandoval-Velasco, M., Gunnarsdóttir, E.D., Jagadeesan, A., Guðmundsdóttir, V.B., Thordardóttir, E. L., et al. 2018. Ancient Genomes from Iceland Reveal the Making of a Human 
Population. Science, 360: 1028-32. https:// doi.org/10.1126/science.aar2625

Effros, B. 2000. Skeletal Sex and Gender in Merovingian Mortuary Archaeology. Antiquity, 74: 632-39.

Erä-Esko, L., Huurre, M., Purhonen, P. \& Sarkki-Isomaa, S. 1995. Suomen esibistoria. Suomen kansallismuseon näyttelyluettelo. Vammala: Museovirasto.

Fausto-Sterling, A. 1992. Myths of Gender: Biological Theories About Men and Women. Revised edition. New York: Basic Books.

Fausto-Sterling, A. 2012. Sex/Gender: Biology in a Social World. New York \& London: Routledge.

Fausto-Sterling, A. 2020. Sexing the Body, Gender Politics and the Construction of Sexuality. Updated edition. New York: Basic Books.

Fu, Q., Posth, C., Hajdinjak, M., Petr, M., Mallick, S., Fernandes, D., et al. 2016. The Genetic History of Ice Age Europe. Nature, 534: 200-05. https://doi.org/10. 1038/nature17993

Gardela, L. 2013. 'Warrior-Women' in Viking Age Scandinavia? A Preliminary Archaeological Study. Analecta Archaeologica Ressoviensia, 8: 273-339.

Gilchrist, R. 1999. Gender and Archaeology: Contesting the Past. London: Routledge.

Hadley D.M. 2008. Warriors, Heroes, and Companions: Negotiating Masculinity in Viking-Age England. In: S. Crawford \& H. Hamerow, eds. Anglo-Saxon Studies in Archaeology and History. Oxford: Oxford University School of Archaeology, pp. 270-84.

Härke, H. 2014. Grave Goods in Early Medieval Burials: Messages and Meanings. Mortality, 19: 41-60.

Harrison, S.H. 2015. 'Warrior Graves'? The Weapon Burial Rite in Viking Age Britain and Ireland. In: J.H. Barrett \& S.J. Gibbon, eds. Maritime Societies of the Viking and Medieval World (Society for Medieval Archaeology monograph 37). Leeds: Maney, pp. 299-319.

Hedeager, L. 2011. Iron Age Myth and Materiality: An Archaeology of Scandinavia $A D$ 400-1000. London \& New York: Routledge.

Hedenstierna-Jonson, C., Kjellström, A., Zachrisson, T., Krzewińska, M., Sobrado, V., Price, N., et al. 2017. A Female Viking Warrior Confirmed by Genomics.
American Journal of Physical Antbropology, 164: 853-60. https://doi.org/10.1002/ajpa. 23308

Herlihy, A.S. \& Gillam, L. 2011. Thinking Outside the Square: Considering Gender in Klinefelter Syndrome and 47, XXY. International Journal of Andrology, 34: e348-e349. https://doi.org/10.1111/j. 1365-2605.2010.01132.x

Hjørungdal, T. 1994. Poles Apart? Have There Been Any Male and Female Graves? Current Swedish Archaeology, 2: 141-49.

Huurre, M. 2009. 9000 vuotta Suomen esibistoriaa. 10th edition. Keuruu: Otava.

Jakobsson, M. 1992. Krigarideologi och vikingatida svärdstypologi (Stockholm Studies in Archaeology, 11). Stockholm: Stockholms universitet.

Joel, D., Berman, Z., Tavor, I., Wexler, N., Gaber, O., Stein, Y., et al. 2015. Sex Beyond the Genitalia: The Human Brain Mosaic. Proceedings of the National Academy of Sciences, 112: 15,468-73. https://doi.org/10.1073/pnas.1509654112

Joel, D., Garcia-Falgueras, A. \& Swaab, D. 2020. The Complex Relationships Between Sex and the Brain. The Neuroscientist, 26: 156-69. https://doi.org/ 10.1177/1073858419867298

Joyce, R.A. 2008. Ancient Bodies, Ancient Lives: Sex, Gender, and Archaeology. London \& New York: Thames \& Hudson.

Keskitalo, O. 1969a. Kertomus myöhäisrautakautisen ruumishaudan tutkimisesta Suontaan kartanon Vesitorninmäessä Tyrvännön pitäjässä 25.10.1968. Unpublished excavation report. Helsinki: Finnish Heritage Agency.

Keskitalo, O. 1969b. Suontaka-svärdet. Finskt Museum, 76: 83-98.

Kirkinen, T. 2015. The Role of Wild Animals in Death Rituals: Furs and Animal Skins in the Late Iron Age Inhumation Burials in Southeastern Fennoscandia. Fennoscandia archaeologica, 32: 101-20.

Kirkinen, T. 2019. Between Skins: Animal Skins in the Iron Age and Historical Burials in Eastern Fennoscandia ( $\mathrm{PhD}$ dissertation, University of Helsinki). Available online at: <http://urn.fi/URN: ISBN:978-951-51-4902-2>

Kirkinen, T., Riikonen, J., Dove, C. \& Ruohonen, J. 2020. The Identification and Use of Fur and Feathers Excavated from the Late Iron Age and Early Medieval 
(12th-13th Centuries) Ravattula Ristimäki Cemetery in Kaarina, Southwest Finland. Fennoscandia Archaeologica, 37: 45-59.

Laqueur, T. 1990. Making Sex: Body and Gender from the Greeks to Freud. Cambridge (MA): Harvard University Press.

Lehtosalo-Hilander, P.-L. 1982. Luistari II. The Artefacts (Suomen Muinaismuistoyhdistyksen Aikakauskirja 82:2). Helsinki: The Finnish Antiquarian Society.

Lehtosalo-Hilander, P.-L. 1983. Gutarnas förbindelser med Finland. In: I. Jansson, ed. Gutar och Vikingar. Stockholm: Statens Historiska Museum, pp. 288-305.

Lehtosalo-Hilander, P.-L. 1984. Ancient Finnish Costumes. Vammala: The Finnish Archaeological Society.

Löfström, J. 1998. Changing Conceptions of Gender Polarity in Finland. In: S. Apo, A. Nenola \& L. Stark-Arola, eds. Gender and Folklore: Perspectives on Finnish and Karelian Culture (Studia Fennica Folkloristica 4). Helsinki: Finnish Literature Society, pp. 239-59.

Lund, J. \& Moen, M. 2019. Hunting Identities: Intersectional Perspectives on Viking Age Mortuary Expressions. Fennoscandia archaeologica, 36: 142-55.

Mägi, M. 2002. At the Crossroads of Space and Time: Graves, Changing Society, and Ideology on Saaremaa (Ösel), 9th-13th Centuries $A D$. Tallinn: Institute of History.

Margaryan, A., Lawson, D.J., Sikora, M., Racimo, F., Rasmussen, S., Moltke, I., et al. 2020. Population Genomics of the Viking World. Nature, 585: 390-96. https://doi.org/10.1038/s41586-020-2688-8

McLeod, S. 2011. Warriors and Women: The Sex Ratio of Norse Migrants to Eastern England up to 900 AD. Early Medieval Europe, 19: 332-53.

Mittnik, A., Wand, C.C., Svoboda, J. \& Krause, J. 2016. A Molecular Approach to the Sexing of the Triple Burial at the Upper Paleolithic Site of Dolní Věstonice. PLoS One, 11: e0163019. https://doi.org/ 10.1371/journal.pone.0163019

Moen, M. 2019. Gender and Archaeology: Where Are We Now? Archaeologies, 15: 206-26. https://doi.org/10.1007/s11759019-09371-w

Moilanen, M. 2015. Marks of Fire, Value, and Faith: Swords with Ferrous Inlays in Finland during the Late Iron Age (ca. 700$1200 A D$ ) (Archaeologia Medii Aevi
Finlandiae, 21). Turku: Society for Medieval Archaeology in Finland.

Moisio, J. 2016. Lisiä Maarian Kärsämäen kalmiston tutkimuksiin - androsentrismistä kohti monipuolisempaa tulkintaa. Muinaistutkija, 4: 18-31.

Motschenbacher, H. 2010. Language, Gender, and Sexual Identity: Poststructuralist Perspectives. Amsterdam \& Philadelphia: John Benjamins.

Nielsen, J. \& Wohlert, M. 1991. Chromosome Abnormalities Found Among 34,910 Newborn Children: Results from a 13-Year Incidence Study in Århus, Denmark. Human Genetics, 87: 81-83. https://doi.org/ 10.1007/BF01213097

Nixon, L. 1994. Gender Bias in Archaeology. In: L.J. Archer, S. Fischler \& M. Wyke, eds. Women in Ancient Societies. London: Macmillan, pp. 1-23.

Nylén, E. 1973. Finskt, gotlänskt eller nordiskt. Kring ett ovanligt exempel på sen runstenornamentik. In: P. Sarvas \& A. Siiriäinen, eds. Honos Ella Kivikoski (Suomen Muinaismuistoyhdistyksen Aikakauskirja, 75). Helsinki: The Finnish Antiquarian Society, pp. 161-68.

Ojanen, E. 2002. Tyrvännön historia. Hämeenlinna: Tyrväntö-seura ry.

Pentz, P., Varberg, J. \& Sørensen, L. 2019. Meet the Vikings: For Real! Antiquity, 93: Project Gallery [online] [accessed 11 March 2021]. https://doi.org/10.15184/aqy.2019.80

Petré, B. 1993. Male and Female Finds and Symbols in Germanic Iron Age Graves. Current Swedish Archaeology, 1: 149-54.

Price, N. 2002. The Viking Way: Religion and War in Late Iron Age Scandinavia (Aun, 31). Uppsala: Department of Archaeology and Ancient History, Uppsala University.

Price, N., Hedenstierna-Jonson, C., Zachrisson, T., Kjellström, A., Storå, J., Krzewińska, M., et al. 2019. Viking Warrior Women? Reassessing Birka Chamber Grave Bj.581. Antiquity, 93: 181-98. https://doi.org/10.15184/aqy. 2018.258

Raninen, S. 2005. Big Men on the River Banks: Some Thoughts on the Middle Merovingian Period Weapon Burials in Finland. In: S. Mäntylä, ed. Rituals and Relations: Studies on the Society and Material Culture of the Baltic Finns. Helsinki: The Finnish Academy of Science and Letters, pp. 224-45. 
Raninen, S. 2006. Tuskan teatteri Turun Kärsämäessä. II osa: Väkivalta varhaisrautakauden kontekstissa. Muinaistutkija, 3: 2-22.

Raninen, S. 2008. Queer Vikings? Transgression of Gender and Same-Sex Encounters in the Late Iron Age and Early Medieval Scandinavia. SQS Suomen Queer-tutkimuksen Seuran lehti, 3: 20-29.

Raninen, S. \& Wessman, A. 2016. Rautakausi. In: G. Haggrén, P. Halinen, M. Lavento, S. Raninen \& A. Wessman, eds. Muinaisuutemme jäljet. Viljandi: Gaudeamus University of Helsinki, pp. 215-368.

Rast-Eicher, A. 2016. Fibres: Microscopy of Archaeological Textiles and Furs. Budapest: Archaeolingua.

Reich, D., Green, R., Kircher, M., Krause, J., Patterson, N., Durand, E.-Y., et al. 2010. Genetic History of an Archaic Hominin Group from Denisova Cave in Siberia. Nature, 468: 1053-60. https://doi.org/10. 1038/nature09710

Reimer, P.J., Austin, W., Bard, E., Bayliss, A., Blackwell, P., Bronk Ramsey, C., et al. 2020. The IntCal20 Northern Hemisphere Radiocarbon Age Calibration Curve (0-55 cal kBP). Radiocarbon, 62: 725-57. https://doi.org/10.1017/RDC. 2020.41

Rivollat, M., Jeong, C., Schiffels, S., Küçükkalipçi, I., Pemonge, M.-H., Rohrlach, A.B., et al. 2020. Ancient Genome-Wide DNA from France Highlights the Complexity of Interactions Between Mesolithic Hunter-Gatherers and Neolithic Farmers. Science Advances, 6: eaaz5344. https://doi.org/10.1126/sciadv. aaz 5344

Sayer, D., Sebo, E. \& Hughies, K. 2019. A Double-Edged Sword: Swords, Bodies, and Personhood in Early Medieval Archaeology and Literature. European Journal of Archaeology, 22: 542-66. https:// doi.org/10.1017/eaa.2019.18

Simniškytè, A. 2007. Weapons in Iron Age Women's Graves. In: A. Bliujienè, ed. Weapons, Weaponry, and Man: In Memoriam Vytautas Kazakevicius (Archaeologia Baltica, 8). Klaipeda: Klaipèda University Press, pp. 283-91.

Sindbæk, S.M. 2019. 'Meet the Vikings'-or Meet Halfway? The New Viking Display at the National Museum of Denmark in Copenhagen. Antiquity, 93: 256-59.

Skoglund, P.J., Storå, A., Götherström, M. \& Jakobsson, M. 2013. Accurate Sex Identification of Ancient Human Remains Using DNA Shotgun Sequencing. Journal of Archaeological Science, 40: 4477-82. https://doi.org/10.1016/j.jas.2013.07.004

Skoglund, P., Northoff, B.H., Shunkov, M. V., Derevianko, A.P., Pääbo, S., Krause, J. \& Jakobsson, M. 2014. Separating Endogenous Ancient DNA from Modern Day Contamination in a Siberian Neandertal. Proceedings of the National Academy of Sciences of the USA, 111: 222934. 1318934111

Sofaer, J.R. 2006. Gender, Bioarchaeology, and Human Ontogeny. In: R. Gowland \& C. Knüsel, eds. The Social Archaeology of Funerary Remains. Oxford: Oxbow Books, pp. 155-67.

Solli, B. 1999a. Odin the Queer: On Ergi and Shamanism in Norse Mythology. In: A. Gustafsson \& H. Karlsson, eds. Glyfer och arkeologiska rum - en vänbok till Jarl Nordbladh (Gotarc Series A, 3). Göteborg: Göteborgs Universitet, pp. 341-50.

Solli, B. 1999b. Queer Theory og gamle guder. Skeive perspektiv på norrøn mytologi. In: T. Markussen \& A.T. Lothrington, eds. Kritisk kunnskapspraksis: Bidrag til feministisk vitenskapsteori. Oslo: Spartacus, pp. 241-64.

Sørensen, M.L.S. 2000. Gender Archaeology. Cambridge: Polity Press.

Stark-Arola, L. 1998. Gender, Magic, and Social Order: Pairing, Boundaries, and the Female Body in Finnish-Karelian Folklore. In: S. Apo, A. Nenola \& L. Stark-Arola, eds. Gender and Folklore: Perspectives on Finnish and Karelian Culture (Studia Fennica Folkloristica, 4). Helsinki: Finnish Literature Society, pp. 31-62.

Stratton, S. 2016. 'Seek and you Shall Find.' How the Analysis of Gendered Patterns in Archaeology can Create False Binaries: A Case Study from Durankulak. Journal of Archaeological Method and Theory, 23: 854-69.

Taavitsainen, J.-P. 1990. Ancient Hillforts of Finland: Problems of Analysis, Chronology and Interpretation with Special Reference to the Hillfort of Kubmoinen (Suomen muinaismuistoyhdistyksen aikakausikirja, 94). 
Helsinki: The Finnish Antiquarian Society.

Troutman, L., Moffatt, C. \& Simmons, T. 2014. A Preliminary Examination of Differential Decomposition Patterns in Mass Graves. Journal of Forensic Sciences, 59: 621-26.

Venäläinen, A., Tuomenvirta, H., Lahtinen, R. \& Heikinheimo, M. 2001. The Influence of Climate Warming on Soil Frost on Snow-Free Surfaces in Finland. Climatic Change, 50: 111-28.

Visootsak, J. \& Graham, J.M. 2006. Klinefelter Syndrome and Other Sex Chromosomal Aneuploidies. Orphanet Journal of Rare Diseases, 1: 42. https://doi. org/10.1186/1750-1172-1-42

Wallis, R.J. 2001. Waking Ancestor Spirits: Neo-Shamanic Engagements with Archaeology. In: N. Price, ed. The Archaeology of Shamanism. London: Routledge, pp. 213-30.

Weismantel, M. 2013. Towards a Transgender Archaeology: A Queer Rampage Through Prehistory. In: S. Stryker \& A.Z. Aizura, eds. The Transgender Studies Reader 2. New York \& Abingdon: Routledge, pp. 319-34.

Wessman, A. 2010. Death, Destruction, and Commemoration: Tracing Ritual Activities in Finnish Late Iron Age Cemeteries (AD 550-1150) (Iskos, 18). Helsinki: The Finnish Antiquarian Society.

Zachrisson, I. 1997. Gåvor eller handel? In: I. Zachrisson, ed. Möten i gränsland. Samer och germaner $i$ Mellanskandinavien (Stockholm Monographs, 4). Stockholm: Statens historiska museum, pp. 148-50.

\section{Biographical Notes}

Ulla Moilanen is a doctoral student at the Department of Archaeology, University of Turku. Her dissertation examines atypical burials in early medieval Finland from the perspective of social microarchaeology and contextualization. Her interests include Iron Age and early medieval burial practices and material culture, the archaeology of individuals, and interdisciplinary archaeology.
Address: Department of Archaeology, University of Turku, FI-20014 University of Turku, Finland. [email: ummoil@utu. fi]. ORCiD: https://orcid.org/0000-00024213-4061

Tuija Kirkinen is a postdoctoral researcher at the Department of Cultures, University of Helsinki. She is specialized in animal hair identification, furs, microarchaeology, and human-animal relationships. Her $\mathrm{PhD}$ study dealt with the role of furs in Late Iron Age and medieval burials in Finland and Karelia.

Address: Department of Cultures, Archaeology, P.O. Box 59, FI-00014 University of Helsinki, Finland. [email: tuija.kirkinen@helsinki.fi]._ ORCiD: https://orcid.org/0000-0001-5572-4426

Nelli-Johanna Saari received her MSc in Archaeological Science at Durham University. She is an MA Archaeology student at the University of Helsinki and a research assistant for the SUGRIGE project at the University of Helsinki and the Department of Archaeogenetics at the Max Planck Institute for the Science of Human History in Jena. Her research interests include archaeogenetics, prehistoric burial practices, kinship networks, and dietary reconstruction.

Address: Department of Archaeogenetics, Max Planck Institute for the Science of Human History, Jena, Germany. [email: saari@shh.mpg.de].

Adam B. Rohrlach is a postdoctoral researcher in the Department of Archaeogenetics at the Max Planck 
Institute for the Science of Human History in Jena. He obtained his $\mathrm{PhD}$ in Mathematical Sciences at the University of Adelaide (Australia). His research interests involve population genetics for Neolithic to Late Bronze Age Europe, and methods development for phylogenetics and population genetics in general.

Address: Department of Archaeogenetics, Max Planck Institute for the Science of Human History, Jena, Germany. [email: rohrlach@shh.mpg.de]. ORCiD: https:// orcid.org/0000-0002-4204-5018

Johannes Krause is professor of archaeogenetics at the Friedrich Schiller University in Jena and director of the Max Planck Institute for Evolutionary Anthropology in Leipzig. His research interests include genetic history, ancient pathogen genomics, and human evolution.

Address: Department of Archaeogenetics, Max Planck Institute for Evolutionary Anthropology, Leipzig, Germany. [email: krause@eva.mpg.de]. ORCiD: https:// orcid.org/0000-0001-5475-4690

Päivi Onkamo is professor of evolutionary genomics at the University of Turku. She is the project manager of SUGRIGE project (Universities of Turku and Helsinki, Finland), which focuses on ancient human genes of north-eastern Europe, especially Uralic-speaking areas. She also heads the Centre of Evolutionary Applications, which is a modern DNA service laboratory at the Department of Biology, University of Turku.

Address: Department of Biology, University of Turku, FI-20014 University of Turku, Finland. [email: paivi.onkamo@ utu.fi].

Elina Salmela is a postdoctoral researcher in the SUGRIGE project at the Universities of Turku and Helsinki and a visiting postdoctoral researcher in the Department of Archaeogenetics at the Max Planck Institute for the Science of Human History in Jena. Her research interests include the genetic population history of north-eastern Europe, based on ancient and extant individuals, and computational methods for such research.

Address: Organismal and Evolutionary Biology Research Programme, University of Helsinki, FI-00014 University of Helsinki, Finland. [email: elina.salmela@ iki.fi]. ORCiD: https://orcid.org/00000003-1326-4462

Une sépulture contenant des fibules et des armes fut découverte en 1968 à Suontaka Vesitorninmäki, Hattula, en Finlande. Depuis, on l'a interprétée comme preuve qu'il existait des femmes au pouvoir, voire des femmes-guerrières, au début du Moyen Âge en Finlande. D'autres ont nié la possibilité d'une sépulture de femme accompagnée d'une épée et ont tenté d'attribuer la présence d'armes à une sépulture double. Les auteurs de cet article présentent la première étude moderne qui examinât le contexte de cette sépulture, les micro-restes conservés dans le sol et l'ADN ancien (aDNA) du squelette. Ces analyses suggèrent une nouvelle interprétation : la sépulture de Suontaka aurait pu appartenir à un individu à chromosomes sexuels XXY aneuploïdes. Le contexte de la sépulture indique qu'il s'agissait d'une personne respectée de genre non-binaire. Translation by Madeleine Hummler 
Mots clés: ADN ancien (aDNA), archéologie funéraire, syndrome de Klinefelter, chromosomes $\mathrm{XXY}$, sépultures à épées, archéologie du genre

\section{Eine Frau mit einem Schwert? - Das Waffengrab von Suontaka Vesitorninmäki in Finnland}

In 1968 wurde ein Waffengrab mit Fibeln in Suontaka Vesitorninmäki in Hattula (Finnland) entdeckt. Seitdem hat man das Grab als Berweis angesehen, dass es Frauen, die Macht ausübten, oder sogar Kriegerinnen im frühmittelalterlichen Finnland gab. Andere haben es ausgeschlossen, dass man eine Frau mit einem Schwert bestattet bätte, und haben versucht, den Befund als Doppelbestattung zu erklären. Die Autoren dieses Artikels legen die erste moderne Untersuchung des Befundes vor, in welcher sie den Kontext der Bestattung in Betracht ziehen und Micro-Resten im Boden und die aDNA des Skeletts analysieren. Diese Untersuchungen lassen eine neue Deutung zu: Bei der Bestattung von Suontaka handelte es sich vielleicht um ein Individuum mit chromosomaler Aneuploidie XXY. Der allgemeine Kontext des Grabes weist auf eine angesehene Person nicht-binären Geschlechtes hin. Translation by Madeleine Hummler

Stichworte: aDNA, Bestattungsarchäologie, Klinefelter-Syndrom, XXY Chromosomen, Waffengräber, archäologische Geschlechterforschung 